\title{
Proteome signatures-how are they obtained and what do they teach us?
}

\author{
João Pinto da Costa ${ }^{1,2}$ • Virginia Carvalhais ${ }^{1,5}$ • Rita Ferreira ${ }^{1}$ - Francisco Amado ${ }^{1}$. \\ Manuel Vilanova $^{3,4} \cdot$ Nuno Cerca $^{5} \cdot$ Rui Vitorino ${ }^{1,2}$
}

Received: 8 May 2015 / Revised: 18 June 2015 / Accepted: 23 June 2015 / Published online: 24 July 2015

(C) Springer-Verlag Berlin Heidelberg 2015

\begin{abstract}
The dawn of a new Proteomics era, just over a decade ago, allowed for large-scale protein profiling studies that have been applied in the identification of distinctive molecular cell signatures. Proteomics provides a powerful approach for identifying and studying these multiple molecular markers in a vast array of biological systems, whether focusing on basic biological research, diagnosis, therapeutics, or systems biology. This is a continuously expanding field that relies on the combination of different methodologies and current advances, both technological and analytical, which have led to an explosion of protein signatures and biomarker candidates. But how are these biological markers obtained? And, most importantly, what can we learn from them? Herein, we
\end{abstract}

João Pinto da Costa and Virginia Carvalhais contributed equally to this work.

Electronic supplementary material The online version of this article (doi:10.1007/s00253-015-6795-7) contains supplementary material, which is available to authorized users.

Rui Vitorino

rvitorino@ua.pt

1 Mass Spectrometry Centre, QOPNA, Department of Chemistry, University of Aveiro, 3810-193 Aveiro, Aveiro, Portugal

2 Institute for Biomedicine - iBiMED, Health Sciences Program, University of Aveiro, Aveiro, Portugal

3 IBMC - Instituto de Biologia Molecular e Celular, Rua do Campo Alegre 83, Porto, Portugal

4 ICBAS - Instituto de Ciências Biomédicas Abel Salazar, University of Porto, Rua de Rua de Jorge Viterbo Ferreira 228, 4050-313 Porto, Portugal

5 CEB - Centre of Biological Engineering, LIBRO - Laboratory of Research in Biofilms Rosário Oliveira, University of Minho, Campus de Gualtar, 4710-057 Braga, Portugal briefly overview the currently available approaches for obtaining relevant information at the proteome level, while noting the current and future roles of both traditional and modern proteomics. Moreover, we provide some considerations on how the development of powerful and robust bioinformatics tools will greatly benefit high-throughput proteomics. Such strategies are of the utmost importance in the rapidly emerging field of immunoproteomics, which may play a key role in the identification of antigens with diagnostic and/ or therapeutic potential and in the development of new vaccines. Finally, we consider the present limitations in the discovery of new signatures and biomarkers and speculate on how such hurdles may be overcome, while also offering a prospect for the next few years in what could be one of the most significant strategies in translational medicine research.

Keywords Proteome signatures $\cdot$ Biomarkers $\cdot$ Proteomics . Immunoproteomics

\section{Introduction}

First used in 1995 (Wasinger et al. 1995), the term proteome described the PROTEin analog of the genOME. Comparative studies of the proteomes derived from genomic sequences have proven to be useful tools in gene identification (Paik et al. 2012), as well as in prediction of function and structure (Nabieva et al. 2005), pathways (Pandey and Mann 2000), identification of protein's active sites (Marino and Gladyshev 2012), and phylogenetic studies (Ma et al. 2012). Hence, proteomics, defined as the detailed study of the large-scale study of proteins (Malmström et al. 2005), provides a powerful approach for identifying and studying multiple molecular markers. In fact, proteomic technologies have already been demonstrated to play an important role in diagnostics 
(Kentsis et al. 2013) and drug discovery (Anderson and Kodukula 2014), due to the fact that the proteome is the link between genes, proteins, and phenotype. Currently, some of the best-selling drugs act on specific proteins or are proteins themselves, and the future holds the promise of proteomicbased personalized medicine, more effective and with significantly fewer side effects (Zahedi et al. 2014).

Recent technological advances, as well as the plethora of available genome sequences available at the National Center for Biotechnology Information (NCBI), has allowed an indepth comparison of single-residue and oligopeptide compositions of the corresponding proteomes (Pe'er et al. 2004). However, unlike the genome, which is relatively static, the proteome changes constantly in response to thousands of intra and extracellular stimuli. Consequently, the proteome varies in health and disease and with the nature of each tissue, as well as with the distinct stage of cell development and in response to drug treatments and exposure to environmental changes (Breker and Schuldiner 2014; Vogel and Marcotte 2012). The proteome is, therefore, similar to a snapshot of the proteins present in one sample at a certain point in time.

Hence, the identification of unique patterns of protein expression, biological markers (biomarkers) or proteomic signatures, that are associated with a given condition, is the most promising and rapidly expanding area of proteomics, with current focus on the enhancement of the specificity and sensitivity of these experimental methodologies and assays (Wilson 2013). These signatures are measurable indicators of some biological state or condition, and the National Institutes of Health (USA) defines them as "a characteristic that is objectively measured and evaluated as an indicator of normal biological processes, pathogenic processes, or pharmacologic responses to a therapeutic intervention" (Biomarkers Definitions Working Group 2001). For microorganisms, however, proteomics has often been considered as basic and unsophisticated when compared to studies focusing on higher organisms (Otto et al. 2014), and consequently, techniques for bacterial proteome annotation (including post-translational chemical modifications, signaling peptides, proteolytic events, among others) are still in their early years (Gupta et al. 2007). However, this rather narrow view of this field of proteomics is currently shifting and research is not merely limited to basic in vitro characterization of microorganisms in order to describe the proteome content of a cell at or to unravel the physiological implications of stress, such as starvation (Hecker et al. 2008). Nowadays, we are beginning to resort to microbial proteomics as sophisticated tools in complex settings, such as host-pathogen interactions (Attia et al. 2013), antibiotic resistance (Vranakis et al. 2014), mixed microbial communities (Siggins et al. 2012), antimicrobial properties (Carvalhais et al. 2015a), and microbial metaproteomics (Otto et al. 2014). Microbiological systems have also proven to be adequately suited for the development of workflows in systems biology. Such strategies allow the combination of multiple levels of biological information, namely genomics, transcriptomics, proteomics, and metabolomics (Zhang et al. 2010). Ultimately, this will yield functional systems for the in silico modeling of cellular processes (Rigoutsos and Stephanopoulos 2006; Schmidt et al. 2013).

In higher organisms, immune systems are capable of distinguishing foreign and/or abnormal cells, eliciting an immune response. Currently, proteomics is contributing to the study and identification of immune patterns of protein expression or antigens through immunoproteomics (Tjalsma et al. 2008), thus identifying the immunoproteome, the proteins that constitute the antigenic repertoire of a given organism (Kunnath-Velayudhan and Porcelli 2013). Detection of immunoproteins may provide insights into which proteins may be directly involved in host immune interaction. Therefore, the protein immunoreactive profile may contribute to an infection proteomic signature (Fulton and Twine 2013). Furthermore, analysis of the immunoproteome may improve the understanding of pathogenesis and unravel novel therapeutic targets based on the repertoire of immunogens (Brady et al. 2006).

Despite the considerable advances of immunoproteomics and the vast potential that it has yet to offer, there are still some technical and experimental limitations that need to be overcome.

Considering all the potential that can be harnessed from these biomarkers and proteomic signatures, it is, therefore, necessary to accurately understand how these can be obtained and the available technologies for such purposes.

\section{DE vs. modern proteomics}

Among the first published works in two-dimensional gel electrophoresis $(2 \mathrm{DE})$ proteomics followed by identification are those described by Bow and co-workers (1989) and VanBogelen and Neidhardt (1990). The underlying principles of 2DE, however, can be traced back to the early 1980s and the pioneering work developed by Bjellqvist et al. (1982) and Görg and co-workers (1982). The term "traditional proteomics" refers, therefore, to the use of 2DE gel-based experimental procedures for the identification of proteins.

Two-dimensional gel electrophoresis, although technically challenging in terms of the skills required by the researcher, remains, to this day, an unparalleled technique for top-down proteomics. It exhibits numerous advantages in microbial proteomics, as it allows visualizing fundamental features of bacterial life, such as stress and starvation responses (Hecker et al. 2008; Soufi et al. 2015), as well as metabolic pathways (Kim et al. 2011) and antibiotic resistance mechanisms (Gonçalves et al. 2014; Monteiro et al. 2012). This technique also offers additional advantages, such as the possibility for studying the isoforms of proteins and their modifications. Many proteins 
undergo post-translational modifications (PTM), namely glycosylation, phosphorylation, alkylation, ubiquitination, acetylation, methylation, among others (Soufi et al. 2012). These modifications are essential and known to play a critical role in maintaining protein function, signaling, regulation, and other important cellular processes in all domains of life (Soufi et al. 2012), often exhibiting differences between distinct physiological conditions. In other words, one gene may encompass a large number of protein products and typical 2DE gels allow for the analysis of these isoforms, as PTM will result in shifts in relative mass (e.g., truncation or glycosylation) or isoelectric point $(\mathrm{p} I)$ (e.g., phosphorylations), with concomitant different mobility on a 2DE gel.

Ideally, the in-gel protein detection methods should be very sensitive but also linear in response (i.e., should be able to accurately detect abundance variations) and homogeneous (all classes of proteins should be detected), but this is not often the case (Rabilloud 2012). Despite these amply-known constraints, a frequently neglected limitation is the performance of the 2D electrophoresis itself. The overall efficiency of this system can be severely affected by the quantitative yield of the $2 \mathrm{DE}$, which has been reported to be considerably moderate (20-40\%) (Zhou et al. 2005). Moreover, 2DE has been demonstrated to result in higher losses for poorly soluble proteins (Santoni et al. 2000; Van et al. 2014), hence lacking homogeneity throughout the tested samples. Difference gel electrophoresis (2DIGE) is a variation of $2 \mathrm{DE}$, which allows to visualize differential protein levels in two protein samples (experiment vs. control) by covalently tagging two protein samples with two distinct fluorescent emission spectra compounds, but with identical masses and electrophoretic mobility (Alban et al. 2003). Despite permitting the direct comparison of two distinct samples in one run, gel-to-gel variation is still observable in larger samples (Baggerman et al. 2005).

The consistent and careful analysis of the gel's results is also of the utmost importance. Gel electrophoresis is the only proteomic technique that has dedicated bioinformatics tools, including those that are integrated in the acquisition of 2DErelated equipments (Palagi et al. 2006), although free, opensource programs exist (Table S1, Supplementary information). For other techniques, such as HPLC, the computer programs are merely considered on the basis of their usefulness with the vendor's equipments. These dedicated software packages, however, still exhibit some limitations, namely the inability of processing incompletely separated spots (overlapping and/ or less defined spots), as well as weak spots, often impossible to discern from noise (Rabilloud et al. 2010).

Considering these limitations, gel-free approaches emerged as an attractive alternative to 2DE-based strategies. These methods require less laborious procedures, smaller amounts of sample, exhibit a wider dynamic range, and allow for a better resolution of low abundant proteins, as well as those with extreme $\mathrm{p} I$ values, molecular weights, and hydrophobicity, such as membrane proteins (Amado et al. 2013). Such strategies are particularly relevant in bottomup - or shotgun - proteomics. In shotgun proteomics, a protein mixture is digested into peptides that, in turn, are loaded onto one- or (at least) two-dimensional chromatography-based separation system. Peptides are then eluted into a tandem mass spectrometer, resorting to an automated system, and the resulting tandem mass spectrometry data is analyzed by powerful computational software packages (Sun and Markey 2011). Because peptides are more easily separated by liquid chromatography than proteins, a peptide-based proteomic analysis can be carried out considerably faster and cheaper than complete gel-based studies. Additionally, gel-free proteomic methodology yields higher protein coverage than gelbased methodologies, since detection of low-abundance proteins is favored (Baggerman et al. 2005; Roe and Griffin 2006).

These gel-free techniques are largely centered on a multidimensional system, MudPIT, based on the sequential stacking of strong cation exchange (SCX) beads and reversedphase beads on a biphasic column (Washburn et al. 2001). This ingenious and sophisticated system presents, however, some limitations. In a typical MudPIT analysis, thousands of MS/MS spectra are acquired. This number of spectra requires massive amounts of storage capacity and extremely powerful data analysis systems. Moreover, peptide samples obtained from the digestion of a few hundreds of proteins are very complex and only a fraction of these peptides will be selected for MS/MS. This selection takes place randomly as the peptides are eluted from the column, which results in severe reproducibility issues (Baggerman et al. 2005). Hence, some modifications have been developed to reduce sample complexity and have been reviewed elsewhere (Abdallah et al. 2012; Amado et al. 2013; Baggerman et al. 2005; Titz et al. 2014). It should be noted, however, that all these modified methodologies are based on the key assumption that a protein can be identified based on the sequence of a single or multiple tryptic peptides originating from this protein or that only peptides with a certain amino acid are isolated (Amado et al. 2013). These modifications include isotope labeling (Gygi et al. 1999), COFRADIC - or combined fractional diagonal chromatography (Gevaert and Vandekerckhove 2004), Nteromics (Gevaert et al. 2003), and combinatorial peptidomics (or peptide arrays) (Soloviev et al. 2003). Other strategies are also available, including the emerging technology of protein chips (Fung et al. 2001). A categorization of such techniques is suggested in Fig. 1. Nonetheless, it is possible to find different classifications as proposed by other authors (Abdallah et al. 2012; Otto et al. 2014).

The introduction of matrix-assisted laser desorption/ ionization (MALDI) (Karas and Hillenkamp 1988) and electrospray ionization (ESI) (Fenn et al. 1989) mass spectrometry techniques quickly gave rise to a significant increase 


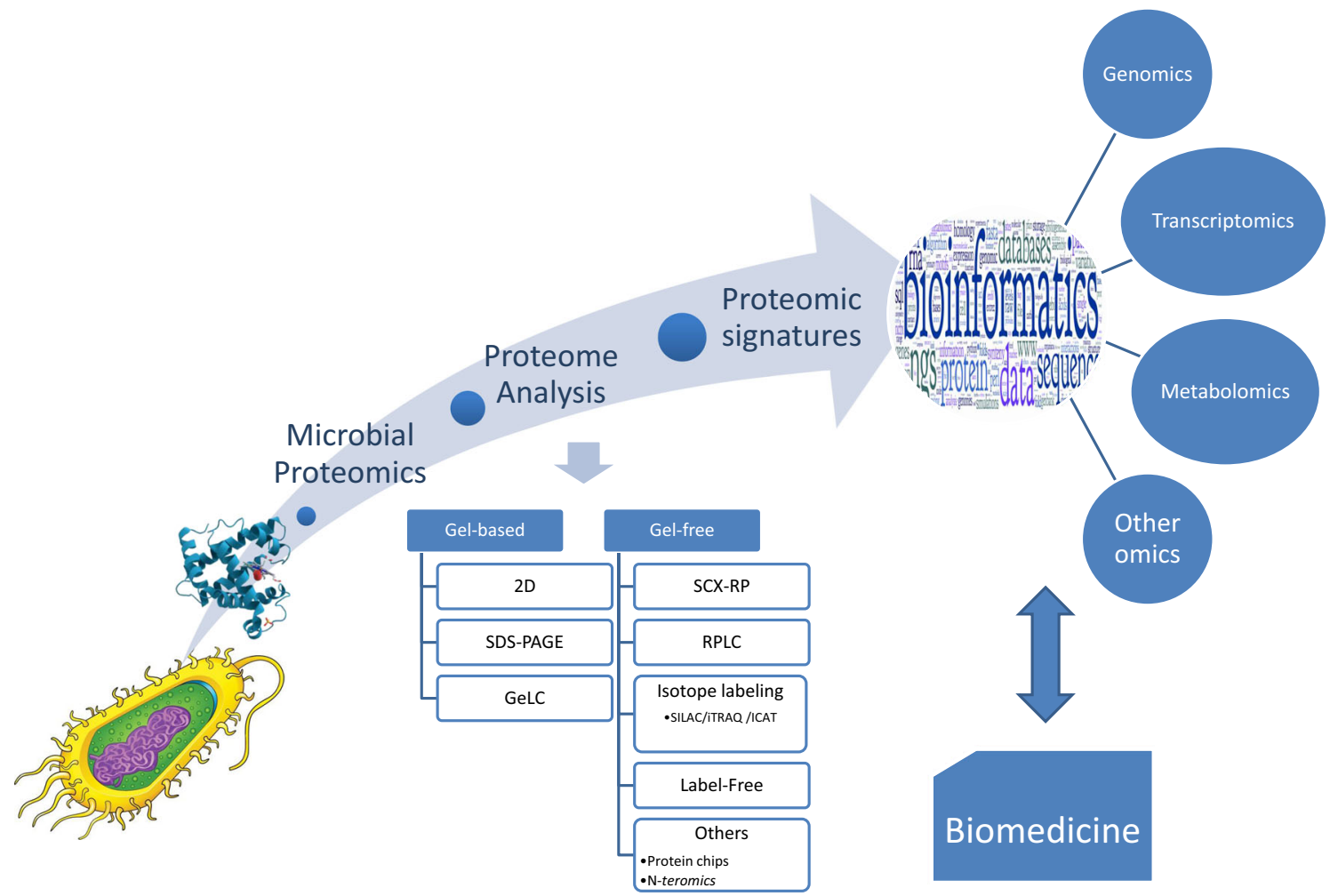

Fig. 1 From proteomics to biomedicine. How the identification of valid proteomic signatures and their integration with other omics and bioinformatic tools can decisively contribute to a better understanding

in works related to protein identification (James et al. 1993; Mann et al. 1993; Pappin et al. 1993; Yates et al. 1993) based on the enzymatic digestion of proteins and included their identification following 2D gel electrophoresis separation. Technological improvements, including the arrival of more accurate instruments, namely the quadrupole time-of-flight mass spectrometer (Q-TOF MS) (Morris et al. 1996), resulted in the development of liquid chromatography-mass spectrometry (LC-MS) methodologies (Yergey 1990). These are powerful techniques that combine the physical separation capabilities of liquid chromatography with the mass analysis capabilities of mass spectrometry and that have consequently allowed for the identification of protein isoforms, which other gel-free methodologies do not permit (Baggerman et al. 2005; Stastna and Van Eyk 2012).

Consequently, most bacterial proteomic studies consist of the use of quantitative tools in the analysis of the changes in the abundance of proteins under carefully regulated experimental conditions, in order to assess the effect of various parameters, such as temperature, nutrients, and environmental stresses (such as exposure to antibiotics) (Carvalhais et al. 2015c; Jain et al. 2011; Hessling et al. 2013). Although these studies often combine both 2D and MALDI time-of-flight mass spectrometry (MALDI-TOF MS) for protein identification, novel non-gel-based, mass spectrometric methods for quantitative proteomics are becoming increasingly important. of key biological questions. A categorization of gel-free and gel-based proteomic strategies is also proposed

Advances in liquid chromatography have resulted in the hyphenation of nanoscale reversed-phase high pressure liquid chromatography (RP-HPLC) to a mass spectrometer, due to the compatibility in solvents, flow rate, high resolution, and reproducibility (Van Oudenhove and Devreese 2013). Other advances include hydrophilic interaction liquid chromatography (HILIC) (Boersema et al. 2008) or ultraperformance liquid chromatography (UPLC) (Soler et al. 2013), and these have been thoroughly reviewed elsewhere (Wu et al. 2012; Xie et al. 2011). Mass spectrometry itself has also undergone technological advancements. The basic types of mass analyzers remain the quadrupole $(\mathrm{Q})$, the time-of-flight (TOF) analyzer, the ion trap, the Fourier transform ion cyclotron resonance mass spectrometry (FT-ICR MS), and the Orbitrap, but they have suffered significant enhancements which have yielded improvements in sensitivity, accuracy, dynamic range, speed of analysis, and resolution (Thelen and Miernyk 2012). Ion traps, for example, can easily be coupled to hybrid devices, such as Fourier transform-based mass spectrometers (FTMS) to increase resolution and sensitivity (Van Oudenhove and Devreese 2013). Currently, FTMS is dominated by Orbitrap mass analyzers, as these exhibit not only higher mass resolutions and accuracies but also greater dynamic ranges at lower costs than classical FT-ICR instruments (Hu et al. 2005; Marshall 2000). The Orbitrap technology has been refined and the current quadrupole Orbitrap instrument 
(Q-Exactive) greatly exceeds other configurations regarding the number of peptide/protein identifications (Van Oudenhove and Devreese 2013), as evidenced by the study carried out by Kelkar and co-workers, in which approximately 250 novel peptides were identified in Mycobacterium tuberculosis (Kelkar et al. 2011). Recently, a new Orbitrap hybrid mass spectrometer equipped with a mass filter, a collision cell, a high-field Orbitrap analyzer, and a dual-cell linear ion trap analyzer (Q-OT-qIT) allowed for the comprehensive analysis of the yeast proteome in just over $1 \mathrm{~h}$ of optimized analysis (Hebert et al. 2014), underlying the current technological achievements in mass spectrometry. Additionally, absolute quantification is now within reach of researchers, with the recent introduction of SYNAPT (Waters), which allows for an extensive characterization of complex mixtures, adding an extra dimension of separation, based not only on chromatography and mass resolution but also on molecular size and shape as well (Wang and Hanash 2015).

Ultimately, this suggests that the thorough analysis of mammalian proteomes within several hours is now within technical reach.

A different approach is targeted proteomics. In this approach, the MS instrument is operated in a selected reaction monitoring (SRM) mode. The sample is queried not only for the presence but also for the quantity of a given set of peptides that are specified prior to data acquisition (Marx 2013). Targeted proteomics can, hence, be used in studies that rely on quantitatively accurate and reproducible measurement of proteins, across multiple samples (Rosenberger et al. 2014). However, SRM is currently limited to measurements of only a few thousands transitions per LCMS/MS run (Perez-Riverol 2014). To overcome such limitation, unbiased data-independent acquisition (DIA) strategies have been developed, which do not rely on the detection or knowledge of the precursor ion (Gillet et al. 2012). These methods are based on the cyclic recording of consecutive survey scans and fragment ion spectra for all precursors contained in pre-arranged isolation windows (swaths), throughout the LC time range. This has resulted in SWATH-MS, an alternative approach to proteome quantification that stems from the combination of highly specific DIA methods with novel-targeted data extraction strategies to mine the resulting fragment ion data sets (Perez-Riverol 2014). The concomitant development of OpenSWATH, a software that enables the automated, targeted analysis of data-independent acquisition MS data (Rost et al. 2014), is believed to have the potential to greatly contribute in an unprecedented manner in the qualitative and quantitative probing of proteomes.

So, when searching for relevant proteomic signatures, which methodology is better? What is the best-suited strategy for these studies? Although many opinions - often divergent-have been cast (Abdallah et al. 2012; Baggerman et al. 2005; Hecker et al. 2008; Monteoliva and Albar 2004; Otto et al. 2014), it is becoming increasingly clear that the advantages and drawbacks of both techniques seem to render them complementary. Their use must take into consideration not only each one's inherent advantages and limitations but also the biological question being addressed. Ultimately, the combined use of multiple strategies will yield more accurate and relevant information. When used in parallel, these methodologies provide a broader understanding of the biological question asked. In fact, works focusing on the elucidation of the proteomes of multiple organisms are based on a combination of such strategies, ensuring a thorough and more complete coverage of the proteins present (Majumder et al. 2011; Wang et al. 2014a; Wolff et al. 2007).

No matter the technique used, it is obvious that these revolutionary techniques yielded a plethora of information that required new, powerful tools. As such, computer-based resources, capable of dealing and keeping up with the wealth of data generated, became necessary.

\section{Bioinformatics and high-throughput analysis}

Understanding the sequence, structure, dynamics, and interactions of proteins has been at the heart of biomedical research since its foundation. Mass spectrometry has emerged as a powerful technique to study proteins on a large-scale fashion (Richards et al. 2015), and combined with highly powerful computational methods and experimental strategies (Kumar and Mann 2009), MS-based proteomics now allows for a comprehensive charting of both the intracellular and the extracellular proteomes (Shabbiri et al. 2013; Wendler et al. 2013; Zhou et al. 2014). Consequently, a multitude of quantitative and qualitative data has arisen and the need for computer-based data analysis is of the utmost importance. Therefore, bioinformatics is a crucial component of any proteomic strategy, but none more than quantitative analysis. An adequate combination of proteomics and bioinformatics can be highly synergistic, yielding a truly high-throughput platform (Goh and Wong 2014).

The internet has also allowed for collaborations and data sharing that would have not been previously possible. As a result, many databases, tools, and full-fledged software packages are currently available online, accounting, frequently, with contributions from all over the world.

There are numerous databases, online resources, and depositories that aim at making proteomic data accessible, enabling the integration, mining, and reuse of the data by and to the scientific community. An extensive review of the current state of such databases and resources has been recently published (PerezRiverol et al. 2015), but some of the most commonly used tools are summarized in Table S2 (Supplementary information).

Considering the vast offer of online tools and resources, it may be tempting to forego laboratory techniques carried out in a wet lab. Nonetheless, bioinformatics should not be considered as a replacement for actual experimental work. For 
example, one might use TargetP (Emanuelsson et al. 2007) and other tools (such as Cello (Yu et al. 2006), PSORTb (Nancy et al. 2010) or SignalP (Petersen et al. 2011)), to predict the subcellular location of a given protein or cleavage sites, but such hypothesis should be experimentally confirmed. The prediction of the protein's location, however, can provide an indication of where to start and, consequently, allow for significant time saving. Although most of the now readily available information, in microbiology, is related to Escherichia coli (Agostini et al. 2014; Cotten and Reed 2013; Keseler et al. 2005), the current focus on links between microbial community disequilibria (dysbiosis) and human disease (Del Chierico et al. 2012; Fritz et al. 2013), oncology (Sears and Garrett 2014), environmental microbial community studies (Segata et al. 2013), among others, is a clear indicator of the role that bioinformatics will play in the near future.

Ultimately, the role of bioinformatics is to allow the processing of data, offering the possibility of annotating, clustering, and integrating information gathered from all omic studies-meta-omics.

\section{Multi-resistance (genomics-based assays)}

Currently, it is generally considered that the analysis of the proteome is more meaningful, from a functional point of view, than the analysis of the genome or transcriptome (Southan 2004). Consequently, the development of proteomic studies has increased exponentially due to the suggestion that the genome sequence is not sufficient to elucidate the biological functions of an organism (Aggarwal and Lee 2003). Following the advances in whole-genome sequencing, which provides information regarding pathogen detection and identification, genotyping, determination of virulence factors, and antibiotic-resistant determinants (Fournier et al. 2014), transcriptomic and proteomic methodologies have been widely used to investigate microbial global expression. In order to obtain the quantitative protein expression profile, methodologies such as isobaric tags for relative and absolute quantitation (iTRAQ), stable isotope labeling by amino acids in cell culture (SILAC), area under the curve (AUC), and isotope-coded affinity tags (ICAT) are frequently employed (Abdallah et al. 2012; Otto et al. 2014; Roe and Griffin 2006). Therefore, protein expression profile is not only revealed by the pattern of proteins which are expressed in a certain condition but may also show to what extent every single protein is expressed.

One question remains: how closely messenger RNA "mRNA" levels relate to their corresponding proteins? At the beginning, most studies looked at gene, mRNA, or protein independently. In an attempt to determine the relation between protein and mRNA levels, some studies have shown that, often, the correlation is surprisingly low and differs widely among organisms (Maier et al. 2009; Vogel and Marcotte
2012). Correlation coefficients varied from 0.09 to 0.46 in multi-cellular organisms, from 0.34 to 0.87 in yeasts, whereas in bacteria, the correlations ranged from 0.20 to 0.47 (reviewed in (Vogel and Marcotte 2012)). However, different bacteria growth conditions may affect the concentration of proteins in growing cell populations, changing the correlation between mRNA and protein abundance (Maier et al. 2009; Maier et al. 2011). Organism phenotype may alter due to modifications after transcription and translational biological processes. For instance, PTM were shown to be involved in the regulation and structural stabilization of eukaryotic proteins, molecular localization, protein-protein interaction, and gene regulation (Michard and Doublet 2015; Minguez et al. 2013; Pisithkul et al. 2015; Silva et al. 2013), which contribute for an increased complexity of the proteome.

Nowadays, a combination of omics is becoming an important way to characterize a condition (Carvalhais et al. 2015c; Ghazalpour et al. 2011; Resch et al. 2006). For instance, DNA-sequencing technologies and mass spectrometry are being used to identify microorganisms and test for antimicrobial susceptibility (Didelot et al. 2012), to distinguish commensal from virulent strains (Savijoki et al. 2014), and to identify resistance markers to antimicrobials based on transcriptomic and proteomic profiles (Fischer et al. 2011; Scherl et al. 2006). These types of studies help to determine the antibiotic resistance mechanisms, contributing to unravel potential drug targets or markers that are constitutively expressed by resistant strains regardless of their genetic background, with concomitant potential application as diagnostic targets. More particularly, membrane and extracellular proteins are likely to be of interest for drug development strategies as these proteins are often directly involved in host-pathogen interactions. However, a high number of proteins in all bacteria species remain uncharacterized in relation to function and cellular localization. Additionally, the number of identified proteins is substantially lower than the number of detected transcripts. In opposite, proteomics provides both quantitative and functional data to complement genomics and transcriptomic profiles, since proteomic mass spectrometry is a powerful tool for quantifying changes in global protein expression patterns. For example, the description of the proteome of the inner membrane of Pseudomonas aeruginosa has provided functional insights into membrane-spanning and membraneassociated protein complexes that may play a role in multiresistance (Casabona et al. 2013). Marti and co-workers (2006) identified elongation factors and outer membrane proteins that constituted the platform for the study of antimicrobial resistance in Acinetobacter baumannii. More recently, Ramos et al. described the identification of 14 differentially expressed proteins in vancomycin-exposed Enterococcus strains (Ramos et al. 2015), thus correlating the expression of these proteins to resistance mechanisms. Similar correlations were established by Piras and co-workers, who described 
the differential expression of proteins under multidrug resistance conditions for E. coli (Piras et al. 2012).

We can assume that a combined analysis may yield a comprehensive understanding of a particular physiological state or condition, providing useful insights that may not be deciphered from individual analysis of gene, transcript, or protein expression.

\section{Immunoproteomics}

The term "immunoproteomics" was first introduced in 2001 by Jungblut (2001). Immunoproteomics encompasses the subset of proteins that may be specifically recognized by immune system components and elicit an immune response. It is based on the ability of higher organisms being capable of discriminating foreign or altered-self cells or molecules from self or healthy ones (Tjalsma et al. 2008). Bacteria, virus, fungi, and parasites carry non-self-proteins. However, altered selfproteins may arise in the course of specific diseases, such as cancer, and can also be targeted by immune responses (de Verteuil et al. 2012). In this case, the immunogenicity may be enhanced by abnormal protein expression levels and/or biomolecule modifications, such as misfolding, mutation, or glycosylation. In some circumstances, such as in autoimmune diseases, self-proteins can also induce the generation or be recognized by antibodies (Tjalsma et al. 2008). In other words, the diverse setting of the adaptive immune response is determined by the peptides presented by immune cells, which are derive from pathogens, whether viral, microbial, or cancerous cells (Fulton and Twine 2013). Ultimately, the goal of immunoproteomics is to visualize what is "seen" by the immune system during disease and under normal conditions (Tjalsma et al. 2008). Classical methodologies studying immunological proteins and antigens have been used for many years, such as enzyme-linked immunosorbent assay (ELISA) (Yin et al. 1995), agglutination (D'Hallewin and Baert 1996), and Western blotting (Olson et al. 1990). Traditionally, ELISA has been the most used method for targeted protein quantification and remains the gold standard to date (Pan et al. 2009), providing good specificity and sensitivity. If high-quality antibodies exist, the validation of these unique patterns of protein expression can be a relatively straightforward process (Köhler and Seitz 2012; Petzold et al. 2010), although it remains, to this day, the bottleneck in biomarker research (Diamandis 2012a). However, for many of the most recently discovered candidates in proteomic studies, ELISA is still limited by the lack of availability of highly specific antibodies. Targeted protein quantification relying on mass spectrometry-based approaches can provide an alternative and complementary methodology, capable of precisely detecting a wide variety of proteins via high mass accuracy and/or peptide sequencing (Pan et al. 2009). Comprising a rapidly growing collection of approaches that aim at identifying and measuring antigenic peptides or proteins, immunoproteomics includes gel-based, array-based, mass spectrometry, DNA based, or in silico methodologies (Fulton and Twine 2013) that are actively contributing to a better understanding of health, disease and disease progression, patterns of protein expression, and vaccine candidates.

\section{Immunoproteomics: a doorway into new vaccines?}

The growing resistance to antibiotics and the shortage of new antimicrobials has been the focus of increasing concern in the past decade. The development and spread of antibiotic resistance in bacteria is a universal threat to both humans and animals and, generally, not preventable (Bush et al. 2011; Megraud et al. 2013). Recently, the World Health Organization (WHO) published an alarming report compiling data from 114 countries named "Antimicrobial Resistance - Global Report on surveillance" (2014). High levels of resistance in all regions of the World and significant gaps in tracking antibiotic resistance were found. Additional data included the report of over 450,000 new cases of multi-resistant tuberculosis in 2012 , the widespread resistance to earlier generation of antimalarial drugs in most malaria-endemic countries, a high percentage of nosocomial infections caused by methicillinresistant Staphylococcus aureus (MRSA), and treatment failures due to resistance to last-resort treatments of gonorrhea in 10 countries (WHO, Antimicrobial resistance - fact sheet No 194, updated April 2015). Moreover, the WHO alerted that we may be heading towards a post-antibiotic era, in which common infections can once again kill. Hence, prophylactic therapies to prevent infection by bacterial pathogens, such as vaccination, become of paramount importance.

However, there are many pathogens for which there are no vaccines and some are not effective among all demographics, namely age groups and immunocompromised individuals (Dennehy and McClean 2012).

Immunoproteomics has emerged as a powerful technique for the identification of potential vaccine candidates against multiple pathogenic bacteria, such as Neisseria meningitidis (Hsu et al. 2008), Bordetella pertussis (Altındiş et al. 2009), S. aureus (Harro et al. 2010), among others (Li et al. 2010; Twine et al. 2006; Zhai et al. 2013). Combining proteomics with the detection of antigens that show immunoreactivity allows for the identification of immunogenic proteins/ peptides expressed during infection (Dennehy and McClean 2012). Most studies have been focused on either cell surface or outer membrane proteins (Montero et al. 2014; Newcombe et al. 2014; Wu et al. 2008b; Zhou et al. 2009), as these are the de facto interface for host-pathogen interactions. Additionally, secreted proteins could also be of special interest (Barh et al. 2013; Campbell et al. 2015; Enany et al. 2012; Wang et al. 2014b; Wu et al. 2008a), as these are also primary 
antigen targets of the host immune response and include many virulence factors (Dennehy and McClean 2012). Collectively, their exposure to the host immune system marks these sets of proteins as a rich source of vaccine potential candidates.

Nonetheless, although immunoproteomics is a powerful technique for the identification of candidate antigens, it is only the first step in a long process for the successful development of a protective vaccine and many additional considerations should be made. For example, several immunogenic proteins identified resorting to proteomic approaches for Burkholderia pseudomallei (BipB) (Druar et al. 2008), S. aureus (IsdB and ClfA) (Pier 2013), or N. meningitidis (EF-Tu and GroEL) (Mendum et al. 2009) have failed to confer protection against infection in subsequent animal model studies. Also, attention must be paid to the specificity of strains, as it has been demonstrated that different bacterial strains may elicit different immune responses (Advani et al. 2011), and consequently, vaccine efficiency may vary greatly across strains (Holst et al. 2014). Additionally, it was demonstrated, in vitro, that the Streptococcus pneumoniae antigen profile is affected by the mode of bacterial growth (Blanchette-Cain et al. 2013), which may represent an additional concern in how to obtain an effective vaccine. More importantly, in vitro experimental conditions may not represent the real in vivo situation (Abdelhady et al. 2013; Coenye and Nelis 2010; Nishitani et al. 2015). It is therefore necessary to have a comprehensive insight into the host immune response in order to successfully develop a functional, effective vaccine.

\section{Host-pathogen response}

The future efficacy of a given vaccine may be undercut by phenomena such as serotype replacement (an increase in the incidence of invasive disease caused by non-vaccine serotypes following vaccine introduction (Weinberger et al. 2011)) and serotype switching (a change of serotype of a single clone (Wyres et al. 2013)). Consequently, harnessing the host-pathogen response can be of significance in two distinct and equally key aspects of vaccine development: (a) identification of novel vaccine antigens by determining the immunogenic bacterial proteins from vaccinated, colonized, or convalescing individuals and (b) the enhancement of efficacy of already identified immunogens (Dennehy and McClean 2012). Table 1 summarizes some of the most recent works carried out in both the identification of new antigens as well as on the improvement of identified ones.

\section{Hurdles and shortcomings}

Biomarker research has been continuously expanding, with different combinations of proteomic-based approaches, which depend on the specific clinical context of use. Furthermore, the recent technological and analytical advances have led to an expansion of candidates already being identified and evaluated, and therefore, there is no doubt that mass spectrometric techniques will play a significant role in biomarker research (Frantzi et al. 2014). Regarding immunoproteomics, major progresses are taking place in the development of antigen-profiling methodologies, as antigen profiles that reflect antibody responses are expected to provide an enhanced predictive and diagnostic value when compared to individual antigens (Tjalsma et al. 2008). Unfortunately, multiple candidates have failed in reaching clinical use. This may be due to lack of a gold standard, since no well-performing test can be used to compare potential biomarkers, opening the way to biased observations. Such limitations may be overcome resorting to mathematical models that account for covariate adjustment, as proposed by Li and collaborators (Liu and Zhou 2013), but other constraints are still present, as disease heterogeneity (Lopez et al. 2012) and biomarker development workflow (Diamandis 2012b). In the latter case, this sometimes (rarely) results in fraudulent claims (Samuel Reich 2011), but mostly results in false discoveries that exhibit pre-analytical, analytical, and/or post-analytical shortcomings and whose original performance claims could not be independently reproduced in subsequent validation studies (Diamandis 2010). There are, naturally, true discoveries that have been validated by using robust and reliable techniques, with reproducible and concordant results among different, independent studies that, nonetheless, fail to "reach the clinic." This may be due to failure in decisively contributing to patient care, except for providing some incremental, but clinically not essential information (Kantelhardt et al. 2011). Additional reasons include the insufficient strength of the marker's predictive value (Simon et al. 2006) and the existence of too many false positives/ negatives (limited sensitivity and/or specificity), that often lead to unnecessary invasive confirmatory procedures (Scholler and Urban 2007) or the simple lack of profitability (Diamandis 2012b). However, instead of only extending the conventional approaches that have been used historically, a different approach may be required to overcome such restraints, with the participation of clinicians for the identification of realistic, interesting, and practical proteomic signatures.

Additionally, correlation of proteomic data with other omics still remains a difficult task. However, the exponential advances observed in computer processing power, database technology, and statistical algorithms are successfully contributing to overcome these hurdles. Lastly, sample consumption and sensitivity, namely for the proteomic analyses of biopsy samples, have not yet been fully optimized, although some techniques have been developed to address this issue, such as laser capture microscopy coupled with tandem MS. Absolute quantification will allow researchers to thoroughly standardize and validate data on biomarker candidates across different experimental techniques, platforms/equipment, and laboratories, which, to this day, remains a major challenge in proteomic studies. 
Table 1 Exploitation of the host-response in the identification of new antigens and the enhancement of the efficacy of already identified bacterial antigens

\begin{tabular}{|c|c|c|c|c|}
\hline Strategy & Organism & Results/targets & Observations & References \\
\hline \multirow{10}{*}{$\begin{array}{l}\text { Identification } \\
\text { of new antigens }\end{array}$} & \multirow[t]{2}{*}{ Neisseria meningitidis } & 17 new antigens & Different subcellular localizations & Tsolakos et al. 2014 \\
\hline & & 3 antigens identified & $\begin{array}{l}\text { All outer membrane proteins } \\
\text { (OMP) }\end{array}$ & Williams et al. 2014 \\
\hline & Streptococcus pneumoniae & $\begin{array}{l}6 \text { immunogenic proteins } \\
\text { identified }\end{array}$ & $\begin{array}{l}\text { Secreted protein Gsp-781 showed } \\
\text { high immunogenicity }\end{array}$ & Choi et al. 2012 \\
\hline & \multirow[t]{2}{*}{ Burkholderia pseudomallei } & $\begin{array}{l}12 \text { immunogenic proteins } \\
\text { identified }\end{array}$ & $\begin{array}{l}9 \text { showed to be outer membrane } \\
\text { proteins }\end{array}$ & Harding et al. 2007 \\
\hline & & New antigen OMP85 & Putative outer membrane protein & Su et al. 2010 \\
\hline & Campylobacter jejuni & 14 vaccine candidates & $\begin{array}{l}\text { CadF and CadF cleaved Fn-binding } \\
\text { polypeptides showed high potential }\end{array}$ & Hu et al. 2013 \\
\hline & Helicobacter pylori & $\begin{array}{l}155 \text { immunoreactive } \\
\text { proteins identified }\end{array}$ & $\begin{array}{l}\text { Discerned different } H \text {. pylori disease } \\
\text { phenotypes; } 3 \text { OMP }\end{array}$ & Lahner et al. 2011 \\
\hline & Staphylococcus epidermidis & $\begin{array}{l}19 \text { immunoreactive } \\
\text { proteins identified }\end{array}$ & $\begin{array}{l}\text { Reactivity differences in biofilm } \\
\text { dormancy }\end{array}$ & Carvalhais et al. $2015 \mathrm{~b}$ \\
\hline & Klebsiella pneumoniae & $\begin{array}{l}134 \text { potential } \\
\text { immunoreactive } \\
\text { proteins }\end{array}$ & All OMPs & Bednarz-Misa et al. 2014 \\
\hline & Vibrio parahaemolyticus & $\begin{array}{l}4 \text { immunogenic } \\
\text { proteins identified }\end{array}$ & $\begin{array}{l}\text { Low-abundance OMPs; VP0802 is } \\
\text { highly conserved in Vibrio species }\end{array}$ & Li et al. 2014 \\
\hline \multirow[t]{4}{*}{$\begin{array}{l}\text { Enhancement of } \\
\text { existing vaccines }\end{array}$} & Neisseria meningitidis & Surface lipoprotein FHbp & $\begin{array}{l}\text { Provided broad protection against } \\
\text { serogroup B }\end{array}$ & Granoff 2014 \\
\hline & \multirow[t]{2}{*}{ Mycobacterium tuberculosis } & $\begin{array}{l}\text { DNA vaccine candidate } \\
\text { Rv3407 }\end{array}$ & Improved the vaccine efficacy of $\mathrm{BCG}^{\mathrm{a}}$ & Mollenkopf et al. 2004 \\
\hline & & $\begin{array}{l}\text { Purified exosomes carrying } \\
\text { mycobacterial antigens }\end{array}$ & $\begin{array}{l}\text { Boosted } \mathrm{BCG}^{\mathrm{a}} \text { immunization; may } \\
\text { yield cell-free vaccines }\end{array}$ & Cheng and Schorey 2013 \\
\hline & Mycobacterium bovis & $\begin{array}{l}\text { Hly }{ }^{\mathrm{b}} \text {-secreting recombinant } \\
\text { M. bovis }\end{array}$ & Conferred greater $\mathrm{BCG}^{\mathrm{a}}$ protection & Grode et al. 2005 \\
\hline
\end{tabular}

\footnotetext{
${ }^{\mathrm{a}}$ M. bovis Bacille Calmette-Guérin, an attenuated vaccine for tuberculosis
}

${ }^{\mathrm{b}}$ Membrane-perforating listeriolysin of Listeria monocytogenes

Considerable efforts (and funds) have been dedicated to proteomics towards the discovery of revolutionary biomarkers. Nonetheless, only a few have yielded benefits to patients. Although proteomics holds exciting and promising prospects, it still does not offer a robust and high-throughput system. Most MS techniques are based on a combination of multiple sample preparation - namely, LC separation or immunoaffinity and/or solid phase extraction - that severely impairs a truly high-throughput platform. Hence, in order to improve the prospects of biomarker research, well-defined study designs need to be established. Discovery, verification, and validation phases must encompass multiple checkpoints that, if passed, offer a high probability of establishing valid biomarkers. Furthermore, the participation of clinicians, offering key concurrent clinical background, is of the utmost importance, if we intend to develop clinically relevant biological markers (Diamandis 2012b; Prensner et al. 2012).

\section{Future perspectives}

Despite all the technological advances, robust assay platforms operating under standardized protocols are still lacking, and currently, no single immunoproteomic technology is optimal, with studies rather focusing on a combination of experimental methods. However, clinically useful and validated proteomic markers can be identified resorting to such strategies.

For diagnostic purposes, most of the discovered antigens are presently transferred to ELISA-based assays, despite ELISA's limitations for the testing of extended antigen panels. Hence, it is foreseeable that specialized antigen arrays, such as fluid-phase systems, may replace ELISA-based studies for the clinical use of multiplexed antigen assays in clinical laboratories in the future (Selvaraju and El Rassi 2012; Tjalsma et al. 2008). Regardless of these challenges, antigen-profiling advances will be of great clinical value for screening, diagnosis, prognosis, and monitoring not only infection but also therapeutic intervention in autoimmune diseases and cancer.

Consequently, the potential of immunoproteomics will quickly unravel, and concerting efforts towards testing of multiple biological markers in the same sample may greatly contribute to overcome one of the major problems in proteomic research, sample availability (Vlahou 2013). There is also the need to bridge the gap between bench research and clinical application - similarly to many other fields of research (Roberts et al. 2012), and regulatory requirements need significant 
improvement and simplification, in order to enable a timely implementation of the efforts towards better medicine and patient care (Frantzi et al. 2014).

\section{Conclusion}

The advances in mass spectrometry-based strategies for protein quantification have opened new, broad applications for drug development, clinical diagnosis, and personalized medicine. Conceptually, when complemented with other techniques, such strategies pave the way towards the discovery of proteomic signatures and accurate validation, as well as personalized medicine and therapies.

MS-based techniques have undoubtedly provided a surge of novel protein marker candidates for a wide variety of diseases. These can potentially be validated prior significant investments in both time and resources in pre-clinical testing are made.

Technical improvements in this rapid evolving technology anticipate that the currently observed limitations may be ephemeral. The development of an absolute quantitative platform, with high sensitivity and specificity, capable of detecting multiple proteins/peptides and endowed with the capability of monitoring PTM will provide us an exquisitely powerful tool for the development of better medicine.

Bioinformatic tools will play a key role in this endeavor, although some restrictions still exist, namely data management of the wealth of information obtained. Nonetheless, the ever-expanding computational power may decisively contribute to overcome such limitations in the near future.

Proteomics, and, more specifically, immunoproteomics, is the new promising omics. It is yielding a better understanding of health, disease, and disease progression, offering routes to the discovery of new vaccines, proteomic signatures, and biomarkers. There are, however, limitations that need to be surmounted and the development of a roadmap, identifying the key steps in the discovery of biological markers and validation, is essential. In the end, such proteomic signatures will teach us about disease mechanisms and will grant us useful, actionable information that will yield undeniable benefits for both patients and clinicians and, ultimately, society as a whole.

Acknowledgments VC had an individual Fundação para a Ciência e a Tecnologia (FCT) fellowship (SFRH/BD/78235/2011). NC is an investigator FCT. This work was funded by FCT and COMPETE grants PTDC/BIA-MIC/113450/2009, FCOMP-01-0124-FEDER014309, QOPNA research unit (project PEst-C/QUI/UI0062/2013), iBiMED (UID/BIM/04501/2013) RNEM (National Mass Spectrometry Network), and CENTRO-07-ST24-FEDER-002034. The authors also thank the FCT Strategic Project PEst-OE/EQB/LA0023/2013 and the Project "BioHealth - Biotechnology and Bioengineering approaches to improve health quality", Ref. NORTE-07-0124-FEDER000027, co-funded by the Programa Operacional Regional do Norte (ON.2 - O Novo Norte), QREN, FEDER. The authors also acknowledge the project "Consolidating Research Expertise and Resources on
Cellular and Molecular Biotechnology at CEB/IBB", Ref. FCOMP01-0124-FEDER-027462.

Conflict of interest The authors declare that they have no competing interests.

\section{References}

Abdallah C, Dumas-Gaudot E, Renaut J, Sergeant K (2012) Gel-based and gel-free quantitative proteomics approaches at a glance. Int $\mathrm{J}$ Plant Genomics 2012:494572

Abdelhady W, Bayer AS, Seidl K, Nast CC, Kiedrowski MR, Horswill AR, Yeaman MR, Xiong YQ (2013) Reduced vancomycin susceptibility in an in vitro catheter-related biofilm model correlates with poor therapeutic outcomes in experimental endocarditis due to methicillin-resistant Staphylococcus aureus. Antimicrob Agents Chemother 57(3):1447-1454

Advani A, Gustafsson L, Åhrén C, Mooi FR, Hallander HO (2011) Appearance of Fim3 and ptxP3-Bordetella pertussis strains, in two regions of Sweden with different vaccination programs. Vaccine 29(18):3438-3442

Aggarwal K, Lee KH (2003) Functional genomics and proteomics as a foundation for systems biology. Brief Funct Genomic Proteomic 2(3):175-184

Agostini F, Cirillo D, Livi CM, Delli Ponti R, Tartaglia GG (2014) ccSOL omics: a webserver for solubility prediction of endogenous and heterologous expression in Escherichia coli. Bioinformatics 30(20): 2975-2977

Alban A, David SO, Bjorkesten L, Andersson C, Sloge E, Lewis S, Currie I (2003) A novel experimental design for comparative twodimensional gel analysis: two-dimensional difference gel electrophoresis incorporating a pooled internal standard. Proteomics 3(1): $36-44$

Altındiș E, Tefon BE, Yıldırım V, Özcengiz E, Becher D, Hecker M, Özcengiz G (2009) Immunoproteomic analysis of Bordetella pertussis and identification of new immunogenic proteins. Vaccine 27(4):542-548

Amado FM, Ferreira RP, Vitorino R (2013) One decade of salivary proteomics: current approaches and outstanding challenges. Clin Biochem 46(6):506-517

Anderson D, Kodukula K (2014) Biomarkers in pharmacology and drug discovery. Biochem Pharmacol 87(1):172-188

Attia AS, Cassat JE, Aranmolate SO, Zimmerman LJ, Boyd KL, Skaar EP (2013) Analysis of the Staphylococcus aureus abscess proteome identifies antimicrobial host proteins and bacterial stress responses at the host-pathogen interface. Pathog Dis 69(1):36-48

Baggerman G, Vierstraete E, De Loof A, Schoofs L (2005) Gel-based versus gel-free proteomics: a review. Comb Chem High Throughput Screen 8(8):669-677

Barh D, Barve N, Gupta K, Chandra S, Jain N, Tiwari S, Leon-Sicairos N, Canizalez-Roman A, dos Santos AR, Hassan SS, Almeida S, Ramos RT, de Abreu VA, Carneiro AR, Soares Sde C, Castro TL, Miyoshi A, Silva A, Kumar A, Misra AN, Blum K, Braverman ER, Azevedo V (2013) Exoproteome and secretome derived broad spectrum novel drug and vaccine candidates in Vibrio cholerae targeted by Piper betel derived compounds. PLoS One 8(1):e52773

Bauw G, Van Damme J, Puype M, Vandekerckhove J, Gesser B, Ratz G, Lauridsen J, Celis J (1989) Protein-electroblotting andmicrosequencing strategies in generating protein data bases from two-dimensional gels. Proc Natl Acad Sci 86(20):7701-7705

Bednarz-Misa I, Serek P, Dudek B, Pawlak A, Bugla-Płoskońska G, Gamian A (2014) Application of zwitterionic detergent to the solubilization of Klebsiella pneumoniae outer membrane proteins for 
two-dimensional gel electrophoresis. J Microbiol Methods 107(0): 74-79

Biomarkers Definitions Working Group (2001) Biomarkers and surrogate endpoints: Preferred definitions and conceptual framework. Clin Pharmacol Ther 69(3):89-95

Bjellqvist B, Ek K, Giorgio Righetti P, Gianazza E, Görg A, Westermeier $\mathrm{R}$, Postel W (1982) Isoelectric focusing in immobilized $\mathrm{pH}$ gradients: principle, methodology and some applications. J Biochem Biophys Methods 6(4):317-339

Blanchette-Cain K, Hinojosa CA, Akula Suresh Babu R, Lizcano A, Gonzalez-Juarbe N, Munoz-Almagro C, Sanchez CJ, Bergman MA, Orihuela CJ (2013) Streptococcus pneumoniae biofilm formation is strain dependent, multifactorial, and associated with reduced invasiveness and immunoreactivity during colonization. mBio 4(5): e00745-e00713

Boersema P, Mohammed S, Heck AR (2008) Hydrophilic interaction liquid chromatography (HILIC) in proteomics. Anal Bioanal Chem 391(1):151-159

Brady RA, Leid JG, Camper AK, Costerton JW, Shirtliff ME (2006) Identification of Staphylococcus aureus proteins recognized by the antibody-mediated immune response to a biofilm infection. Infect Immun 74(6):3415-3426

Breker M, Schuldiner M (2014) The emergence of proteome-wide technologies: systematic analysis of proteins comes to age. Nat Rev Mol Cell Biol 15(7):453-464

Bush K, Courvalin P, Dantas G, Davies J, Eisenstein B, Huovinen P, Jacoby GA, Kishony R, Kreiswirth BN, Kutter E (2011) Tackling antibiotic resistance. Nat Rev Microbiol 9(12):894-896

Campbell LT, Simonin AR, Chen C, Ferdous J, Padula MP, Harry E, Hofer M, Campbell IL, Carter DA (2015) Cryptococcus strains with different pathogenic potential have diverse protein secretomes. Eukaryot Cell 14(6):554-563

Carvalhais V, Amado F, Cerveira F, Ferreira R, Vilanova M, Cerca N, Vitorino R (2015a) Immunoreactive pattern of Staphylococcus epidermidis biofilm against human whole saliva. Electrophoresis 36(9-10):1228-1233

Carvalhais V, Cerveira F, Vilanova M, Cerca N, Vitorino R (2015b) An immunoproteomic approach for characterization of dormancy within Staphylococcus epidermidis biofilms. Mol Immunol 65(2):429435

Carvalhais V, Franca A, Pier GB, Vilanova M, Cerca N, Vitorino R (2015c) Comparative proteomic and transcriptomic profile of Staphylococcus epidermidis biofilms grown in glucose-enriched medium. Talanta 132:705-712

Casabona MG, Vandenbrouck Y, Attree I, Coute Y (2013) Proteomic characterization of Pseudomonas aeruginosa PAO1 inner membrane. Proteomics 13(16):2419-2423

Cheng Y, Schorey JS (2013) Exosomes carrying mycobacterial antigens can protect mice against Mycobacterium tuberculosis infection. Eur J Immunol 43(12):3279-3290

Choi C-W, Lee YG, Kwon S-O, Kim H-Y, Lee JC, Chung Y-H, Yun C-Y, Kim SI (2012) Analysis of Streptococcus pneumoniae secreted antigens by immuno-proteomic approach. Diagn Microbiol Infect Dis 72(4):318-327

Coenye T, Nelis HJ (2010) In vitro and in vivo model systems to study microbial biofilm formation. J Microbiol Methods 83(2):89-105

Cotten C, Reed JL (2013) Mechanistic analysis of multi-omics datasets to generate kinetic parameters for constraint-based metabolic models. BMC Bioinf 14:32

D'Hallewin M-A, Baert L (1996) Initial evaluation of the bladder tumor antigen test in superficial bladder cancer. J Urol 155(2):475-476

de Verteuil D, Granados DP, Thibault P, Perreault C (2012) Origin and plasticity of MHC I-associated self peptides. Autoimmun Rev 11(9): 627-635

Del Chierico F, Vernocchi P, Bonizzi L, Carsetti R, Castellazzi AM, Dallapiccola B, de Vos W, Guerzoni ME, Manco M, Marseglia
GL, Muraca M, Roncada P, Salvatori G, Signore F, Urbani A, Putignani L (2012) Early-life gut microbiota under physiological and pathological conditions: the central role of combined metaomics-based approaches. J Proteome 75(15):4580-4587

Dennehy R, McClean S (2012) Immunoproteomics: the key to discovery of new vaccine antigens against bacterial respiratory infections. Curr Protein Pept Sci 13(8):807-815

Diamandis EP (2012a) Biomarker validation is still the bottleneck in biomarker research. J Intern Med 272(6):620

Diamandis EP (2012b) The failure of protein cancer biomarkers to reach the clinic: why, and what can be done to address the problem? BMC Med 10:87

Diamandis EP (2010) Cancer biomarkers: can we turn recent failures into success? J Natl Cancer Inst 102(19):1462-1467

Didelot X, Bowden R, Wilson DJ, Peto TE, Crook DW (2012) Transforming clinical microbiology with bacterial genome sequencing. Nat Rev Genet 13(9):601-612

Druar C, Yu F, Barnes JL, Okinaka RT, Chantratita N, Beg S, Stratilo CW, Olive AJ, Soltes G, Russell ML, Limmathurotsakul D, Norton RE, Ni SX, Picking WD, Jackson PJ, Stewart DI, Tsvetnitsky V, Picking WL, Cherwonogrodzky JW, Ketheesan N, Peacock SJ, Wiersma EJ (2008) Evaluating Burkholderia pseudomallei bip proteins as vaccines and Bip antibodies as detection agents. FEMS Immunol Med Microbiol 52(1):78-87

Emanuelsson O, Brunak S, von Heijne G, Nielsen H (2007) Locating proteins in the cell using TargetP, SignalP and related tools. Nat Protoc 2(4):953-971

Enany S, Yoshida Y, Magdeldin S, Zhang Y, Bo X, Yamamoto T (2012) Extensive proteomic profiling of the secretome of European community acquired methicillin resistant Staphylococcus aureus clone. Peptides 37(1):128-137

Fenn JB, Mann M, Meng CK, Wong SF, Whitehouse CM (1989) Electrospray ionization for mass spectrometry of large biomolecules. Science 246(4926):64-71

Fischer A, Yang SJ, Bayer AS, Vaezzadeh AR, Herzig S, Stenz L, Girard M, Sakoulas G, Scherl A, Yeaman MR, Proctor RA, Schrenzel J, Francois P (2011) Daptomycin resistance mechanisms in clinically derived Staphylococcus aureus strains assessed by a combined transcriptomics and proteomics approach. J Antimicrob Chemother 66(8):1696-1711

Fournier PE, Dubourg G, Raoult D (2014) Clinical detection and characterization of bacterial pathogens in the genomics era. Genome Med 6(11):114

Frantzi M, Bhat A, Latosinska A (2014) Clinical proteomic biomarkers: relevant issues on study design \& technical considerations in biomarker development. Clin Transl Med 3:7-7

Fritz JV, Desai MS, Shah P, Schneider JG, Wilmes P (2013) From metaomics to causality: experimental models for human microbiome research. Microbiome 1(1):14

Fulton K, Twine S (2013) Immunoproteomics: current technology and applications. In: Fulton KM, Twine SM (eds) Immunoproteomics. Methods in molecular biology, vol 1061. Humana Press, pp. 21-57

Fung ET, Thulasiraman V, Weinberger SR, Dalmasso EA (2001) Protein biochips for differential profiling. Curr Opin Biotechnol 12(1):6569

Gevaert K, Goethals M, Martens L, Van Damme J, Staes A, Thomas GR, Vandekerckhove J (2003) Exploring proteomes and analyzing protein processing by mass spectrometric identification of sorted $\mathrm{N}$ terminal peptides. Nat Biotechnol 21(5):566-569

Gevaert K, Vandekerckhove J (2004) COFRADICTM: the Hubble telescope of proteomics. Drug Discovery Today: Targets 3(2):16-22

Ghazalpour A, Bennett B, Petyuk VA, Orozco L, Hagopian R, Mungrue IN, Farber CR, Sinsheimer J, Kang HM, Furlotte N, Park CC, Wen PZ, Brewer H, Weitz K, Camp 2nd DG, Pan C, Yordanova R, Neuhaus I, Tilford C, Siemers N, Gargalovic P, Eskin E, Kirchgessner T, Smith DJ, Smith RD, Lusis AJ (2011) 
Comparative analysis of proteome and transcriptome variation in mouse. PLoS Genet 7(6):e1001393

Gillet LC, Navarro P, Tate S, Rost H, Selevsek N, Reiter L, Bonner R, Aebersold R (2012) Targeted data extraction of the MS/MS spectra generated by data-independent acquisition: a new concept for consistent and accurate proteome analysis. Mol Cell Proteomics 11(6): O111.016717

Goh WWB, Wong L (2014) Computational proteomics: designing a comprehensive analytical strategy. Drug Discov Today 19(3):266-274

Gonçalves A, Poeta P, Monteiro R, Marinho C, Silva N, Guerra A, Petrucci-Fonseca F, Rodrigues J, Torres C, Vitorino R, Domingues P, Igrejas G (2014) Comparative proteomics of an extended spectrum $\beta$-lactamase producing Escherichia coli strain from the Iberian wolf. J Proteome 104(0):80-93

Görg A, Postel W, Westermeier R (1982) Ultrathin-layer horizontal highresolution two-dimensional electrophoresis of legume seed proteins with intermediate protein staining. Z Lebensm Unters Forsch 174(4):286-289

Granoff DM (2014) Improving safety and efficacy of meningococcal vaccines. Microbe Mag 9(8):321-327

Grode L, Seiler P, Baumann S, Hess J, Brinkmann V, Eddine AN, Mann P, Goosmann C, Bandermann S, Smith D, Bancroft GJ, Reyrat J-M, van Soolingen D, Raupach B, Kaufmann SHE (2005) Increased vaccine efficacy against tuberculosis of recombinant Mycobacterium bovis bacille CalmetteGuérin mutants that secrete listeriolysin. J Clin Invest 115(9):2472-2479

Gupta N, Tanner S, Jaitly N, Adkins JN, Lipton M, Edwards R, Romine M, Osterman A, Bafna V, Smith RD, Pevzner PA (2007) Whole proteome analysis of post-translational modifications: applications of mass-spectrometry for proteogenomic annotation. Genome Res 17(9):1362-1377

Gygi SP, Rist B, Gerber SA, Turecek F, Gelb MH, Aebersold R (1999) Quantitative analysis of complex protein mixtures using isotopecoded affinity tags. Nat Biotechnol 17(10):994-999

Harding SV, Sarkar-Tyson M, Smither SJ, Atkins TP, Oyston PC, Brown KA, Liu Y, Wait R, Titball RW (2007) The identification of surface proteins of Burkholderia pseudomallei. Vaccine 25(14):2664-2672

Harro JM, Peters BM, O’May GA, Archer N, Kerns P, Prabhakara R, Shirtliff ME (2010) Vaccine development in Staphylococcus aureus: taking the biofilm phenotype into consideration. FEMS Immunol Med Microbiol 59(3):306-323

Hebert AS, Richards AL, Bailey DJ, Ulbrich A, Coughlin EE, Westphall MS, Coon JJ (2014) The one hour yeast proteome. Mol Cell Proteomics 13(1):339-347

Hecker M, Antelmann H, Büttner K, Bernhardt J (2008) Gel-based proteomics of Gram-positive bacteria: a powerful tool to address physiological questions. Proteomics 8(23-24):4958-4975

Hessling B, Bonn F, Otto A, Herbst FA, Rappen GM, Bernhardt J, Hecker M, Becher D (2013) Global proteome analysis of vancomycin stress in Staphylococcus aureus. Int J Med Microbiol 303(8):624-634

Holst J, Comanducci M, Bambini S, Muzzi A, Comandi S, Oksnes J, DeTora L, Pizza M, Rappuoli R, Caugant DA (2014) Variability of genes encoding surface proteins used as vaccine antigens in meningococcal endemic and epidemic strain panels from Norway. Vaccine 32(23):2722-2731

Hsu CA, Lin WR, Li JC, Liu YL, Tseng YT, Chang CM, Lee YS, Yang CY (2008) Immunoproteomic identification of the hypothetical protein NMB1468 as a novel lipoprotein ubiquitous in Neisseria meningitidis with vaccine potential. Proteomics 8(10):2115-2125

Hu Q, Noll RJ, Li H, Makarov A, Hardman M, Graham Cooks R (2005) The Orbitrap: a new mass spectrometer. J Mass Spectrom 40(4): 430-443

Hu Y, Shang Y, Huang J, Wang Y, Ren F, Jiao Y, Pan Z, X-a J (2013) A novel immunoproteomics method for identifying in vivo-induced Campylobacter jejuni antigens using pre- adsorbed sera from infected patients. Biochim Biophys Acta Gen Subj 1830(11):5229-5235

Jain S, Graham C, Graham RL, McMullan G, Ternan NG (2011) Quantitative proteomic analysis of the heat stress response in Clostridium difficile strain 630. J Proteome Res 10(9):3880-3890

James P, Quadroni M, Carafoli E, Gonnet G (1993) Protein identification by mass profile fingerprinting. Biochem Biophys Res Commun 195(1):58-64

Jungblut PR (2001) Proteome analysis of bacterial pathogens. Microbes Infect 3(10):831-840

Kantelhardt EJ, Vetter M, Schmidt M, Veyret C, Augustin D, Hanf V, Meisner C, Paepke D, Schmitt M, Sweep F, von Minckwitz G, Martin PM, Jaenicke F, Thomssen C, Harbeck N (2011) Prospective evaluation of prognostic factors uPA/PAI-1 in nodenegative breast cancer: phase III NNBC3-Europe trial (AGO, GBG, EORTC-PBG) comparing 6xFEC versus $3 \times \mathrm{FEC} /$ 3xDocetaxel. BMC Cancer 11:140

Karas M, Hillenkamp F (1988) Laser desorption ionization of proteins with molecular masses exceeding 10,000 daltons. Anal Chem 60(20):2299-2301

Kelkar DS, Kumar D, Kumar P, Balakrishnan L, Muthusamy B, Yadav AK, Shrivastava P, Marimuthu A, Anand S, Sundaram H, Kingsbury R, Harsha HC, Nair B, Prasad TSK, Chauhan DS, Katoch K, Katoch VM, Kumar P, Chaerkady R, Ramachandran S, Dash D, Pandey A (2011) Proteogenomic analysis of Mycobacterium tuberculosis by high resolution mass spectrometry. Mol Cell Proteomics 10(12):M111.011627

Kentsis A, Shulman A, Ahmed S, Brennan E, Monuteaux MC, Lee YH, Lipsett S, Paulo JA, Dedeoglu F, Fuhlbrigge R (2013) Urine proteomics for discovery of improved diagnostic markers of Kawasaki disease. EMBO Mol Med 5(2):210-220

Keseler IM, Collado-Vides J, Gama-Castro S, Ingraham J, Paley S, Paulsen IT, Peralta-Gil M, Karp PD (2005) EcoCyc: a comprehensive database resource for Escherichia coli. Nucleic Acids Res 33(suppl 1):D334-D337

Kim SJ, Kweon O, Cerniglia CE (2011) Proteomic applications to elucidate bacterial aromatic hydrocarbon metabolic pathways. In: MooYoung M (ed) Comprehensive biotechnology, 2nd edn. Academic Press, Burlington, pp. 105-114

Köhler K, Seitz H (2012) Validation processes of protein biomarkers in serum - a cross platform comparison. Sens Basel 12(9):12710 12728

Kumar C, Mann M (2009) Bioinformatics analysis of mass spectrometrybased proteomics data sets. FEBS Lett 583(11):1703-1712

Kunnath-Velayudhan S, Porcelli SA (2013) Recent advances in defining the immunoproteome of Mycobacterium tuberculosis. Front Immunol 4:335

Lahner E, Bernardini G, Possenti S, Renzone G, Scaloni A, Santucci A, Annibale B (2011) Immunoproteomics of Helicobacter pylori infection in patients with atrophic body gastritis, a predisposing condition for gastric cancer. Int $\mathrm{J}$ Med Microbiol 301(2):125-132

Li C, Ye Z, Wen L, Chen R, Tian L, Zhao F, Pan J (2014) Identification of a novel vaccine candidate by immunogenic screening of Vibrio parahaemolyticus outer membrane proteins. Vaccine 32(46):61156121

Li H, Ye M-Z, Peng B, Wu H-K, Xu C-X, Xiong X-P, Wang C, Wang SY, Peng X-X (2010) Immunoproteomic identification of polyvalent vaccine candidates from Vibrio parahaemolyticus outer membrane proteins. J Proteome Res 9(5):2573-2583

Liu D, Zhou XH (2013) Covariate adjustment in estimating the area under ROC curve with partially missing gold standard. Biometrics 69(1): $91-100$

Lopez E, Madero L, Lopez-Pascual J, Latterich M (2012) Clinical proteomics and OMICS clues useful in translational medicine research. Proteome Sci 10(1):35 
Ma Y, He Y, Zhao R, Wu Y, Li W, Cao Z (2012) Extreme diversity of scorpion venom peptides and proteins revealed by transcriptomic analysis: implication for proteome evolution of scorpion venom arsenal. J Proteome 75(5):1563-1576

Maier T, Guell M, Serrano L (2009) Correlation of mRNA and protein in complex biological samples. FEBS Lett 583(24):3966-3973

Maier T, Schmidt A, Guell M, Kuhner S, Gavin AC, Aebersold R, Serrano L (2011) Quantification of mRNA and protein and integration with protein turnover in a bacterium. Mol Syst Biol 7:511

Majumder A, Sultan A, Jersie-Christensen RR, Ejby M, Schmidt BG, Lahtinen SJ, Jacobsen S, Svensson B (2011) Proteome reference map of Lactobacillus acidophilus NCFM and quantitative proteomics towards understanding the prebiotic action of lactitol. Proteomics 11(17):3470-3481

Malmström J, Malmström L, Marko-Varga G (2005) Proteomics: a new research area for the biomedical field. J Organ Dysfunct 1(1):83-94

Mann M, Højrup P, Roepstorff P (1993) Use of mass spectrometric molecular weight information to identify proteins in sequence databases. Biol Mass Spectrom 22(6):338-345

Marino SM, Gladyshev VN (2012) Analysis and functional prediction of reactive cysteine residues. J Biol Chem 287(7):4419-4425

Marshall AG (2000) Milestones in fourier transform ion cyclotron resonance mass spectrometry technique development. Int J Mass Spectrom 200(1-3):331-356

Martí S, Sanchez-Cespedes J, Oliveira E, Bellido D, Giralt E, Vila J (2006) Proteomic analysis of a fraction enriched in cell envelope proteins of Acinetobacter baumannii. Proteomics 6(Suppl 1):S82S87

Marx V (2013) Targeted proteomics. Nat Methods 10(1):19-22

Megraud F, Coenen S, Versporten A, Kist M, Lopez-Brea M, Hirschl AM, Andersen LP, Goossens H, Glupczynski Y, Alarcon T (2013) Helicobacter pylori resistance to antibiotics in Europe and its relationship to antibiotic consumption. Gut 62(1):34-42

Mendum TA, Newcombe J, McNeilly CL, McFadden J (2009) Towards the immunoproteome of Neisseria meningitidis. PLoS One 4(6): e5940

Michard C, Doublet P (2015) Post-translational modifications are key players of the Legionella pneumophila infection strategy. Front Microbiol 6:87

Minguez P, Letunic I, Parca L, Bork P (2013) PTMcode: a database of known and predicted functional associations between posttranslational modifications in proteins. Nucleic Acids Res 41(Database issue):D306-D311

Mollenkopf HJ, Grode L, Mattow J, Stein M, Mann P, Knapp B, Ulmer J, Kaufmann SHE (2004) Application of mycobacterial proteomics to vaccine design: improved protection by Mycobacterium bovis BCG Prime-Rv3407 DNA boost vaccination against tuberculosis. Infect Immun 72(11):6471-6479

Monteiro R, Vitorino R, Domingues P, Radhouani H, Carvalho C, Poeta P, Torres C, Igrejas G (2012) Proteome of a methicillin-resistant Staphylococcus aureus clinical strain of sequence type ST398. J Proteome 75(10):2892-2915

Monteoliva L, Albar JP (2004) Differential proteomics: an overview of gel and non-gel based approaches. Brief Funct Genomic Proteomic 3(3):220-239

Montero D, Orellana P, Gutiérrez D, Araya D, Salazar JC, Prado V, Oñate Á, del Canto F, Vidal R (2014) Immunoproteomic analysis to identify Shiga toxin-producing Escherichia coli outer membrane proteins expressed during human infection. Infect Immun 82(11): 4767-4777

Morris HR, Paxton T, Dell A, Langhorne J, Berg M, Bordoli RS, Hoyes J, Bateman RH (1996) High sensitivity collisionally-activated decomposition tandem mass spectrometry on a novel quadrupole/ orthogonal-acceleration time-of-flight mass spectrometer. Rapid Commun Mass Spectrom 10(8):889-896
Nabieva E, Jim K, Agarwal A, Chazelle B, Singh M (2005) Wholeproteome prediction of protein function via graph-theoretic analysis of interaction maps. Bioinformatics 21(suppl 1):i302-i310

Nancy YY, Wagner JR, Laird MR, Melli G, Rey S, Lo R, Dao P, Sahinalp SC, Ester M, Foster LJ (2010) PSORTb 3.0: improved protein subcellular localization prediction with refined localization subcategories and predictive capabilities for all prokaryotes. Bioinformatics 26(13):1608-1615

Newcombe J, Mendum TA, C-p R, McFadden J (2014) Identification of the immunoproteome of the meningococcus by cell surface immunoprecipitation and MS. Microbiology 160(Pt 2):429-438

Nishitani K, Sutipornpalangkul W, de Mesy Bentley KL, Varrone JJ, Bello-Irizarry SN, Ito H, Matsuda S, Kates SL, Daiss JL, Schwarz EM (2015) Quantifying the natural history of biofilm formation in vivo during the establishment of chronic implant-associated Staphylococcus aureus osteomyelitis in mice to identify critical pathogen and host factors. J Orthop Res. doi:10.1002/jor.22907

Olson MJ, Johnson JT, Reidy CA (1990) A comparison of male rat and human urinary proteins: implications for human resistance to hyaline droplet nephropathy. Toxicol Appl Pharmacol 102(3):524-536

Otto A, Becher D, Schmidt F (2014) Quantitative proteomics in the field of microbiology. Proteomics 14(4-5):547-565

Paik Y-K, Jeong S-K, Omenn GS, Uhlen M, Hanash S, Cho SY, Lee H-J, $\mathrm{Na}$ K, Choi E-Y, Yan F (2012) The chromosome-centric human proteome project for cataloging proteins encoded in the genome. Nat Biotechnol 30(3):221-223

Palagi PM, Hernandez P, Walther D, Appel RD (2006) Proteome informatics I: bioinformatics tools for processing experimental data. Proteomics 6(20):5435-5444

Pan S, Aebersold R, Chen R, Rush J, Goodlett DR, McIntosh MW, Zhang J, Brentnall TA (2009) Mass spectrometry based targeted protein quantification: methods and applications. J Proteome Res 8(2): 787-797

Pandey A, Mann M (2000) Proteomics to study genes and genomes. Nature 405(6788):837-846

Pappin DJC, Hojrup P, Bleasby AJ (1993) Rapid identification of proteins by peptide-mass fingerprinting. Curr Biol 3(6):327-332

Pe'er I, Felder CE, Man O, Silman I, Sussman JL, Beckmann JS (2004) Proteomic signatures: amino acid and oligopeptide compositions differentiate among phyla. Proteins 54(1):20-40

Perez-Riverol Y (2014) SWATH-MS and next-generation targeted proteomics. http://computationalproteomic.blogspot.pt/2014/04/swathms-for-quantitative-experiments.html Accessed June 14th 2015

Perez-Riverol Y, Alpi E, Wang R, Hermjakob H, Vizcaíno JA (2015) Making proteomics data accessible and reusable: current state of proteomics databases and repositories. Proteomics 15(5-6):930-950

Petersen TN, Brunak S, von Heijne G, Nielsen H (2011) SignalP 4.0: discriminating signal peptides from transmembrane regions. Nat Methods 8(10):785-786

Petzold A, Altintas A, Andreoni L, Bartos A, Berthele A, Blankenstein MA, Buee L, Castellazzi M, Cepok S, Comabella M, Constantinescu CS, Deisenhammer F, Deniz G, Erten G, Espiño M, Fainardi E, Franciotta D, Freedman MS, Giedraitis V, Gilhus NE, Giovannoni G, Glabinski A, Grieb P, Hartung H-P, Hemmer B, Herukka S-K, Hintzen R, Ingelsson M, Jackson S, Jacobsen S, Jafari N, Jalosinski M, Jarius S, Kapaki E, Kieseier BC, KoelSimmelink MJA, Kornhuber J, Kuhle J, Kurzepa J, Lalive PH, Lannfelt L, Lehmensiek V, Lewczuk P, Livrea P, Marnetto F, Martino D, Menge T, Norgren N, Papuć E, Paraskevas GP, Pirttilä T, Rajda C, Rejdak K, Ricny J, Ripova D, Rosengren L, Ruggieri M, Schraen S, Shaw G, Sindic C, Siva A, Stigbrand T, Stonebridge I, Topcular B, Trojano M, Tumani H, Twaalfhoven HAM, Vécsei L, Van Pesch V, Vanderstichele H, Vedeler C, Verbeek MM, Villar LM, Weissert R, Wildemann B, Yang C, Yao K, Teunissen CE (2010) 
Neurofilament ELISA validation. J Immunol Methods 352(1-2):2331

Pier GB (2013) Will there ever be a universal Staphylococcus aureus vaccine? Hum Vaccin Immunother 9(9):1865-1876

Piras C, Soggiu A, Bonizzi L, Gaviraghi A, Deriu F, De Martino L, Iovane G, Amoresano A, Roncada P (2012) Comparative proteomics to evaluate multi drug resistance in Escherichia coli. Mol BioSyst 8(4):1060-1067

Pisithkul T, Patel NM, Amador-Noguez D (2015) Post-translational modifications as key regulators of bacterial metabolic fluxes. Curr Opin Microbiol 24:29-37

Prensner JR, Rubin MA, Wei JT, Chinnaiyan AM (2012) Beyond PSA: the next generation of prostate cancer biomarkers. Sci Transl Med 4(127): $127 \mathrm{rv} 3$

Rabilloud T (2012) The whereabouts of 2D gels in quantitative proteomics quantitative methods in proteomics. Springer, pp. 25-35

Rabilloud T, Chevallet M, Luche S, Lelong C (2010) Two-dimensional gel electrophoresis in proteomics: past, present and future. J Proteome 73(11):2064-2077

Ramos S, Chafsey I, Silva N, Hébraud M, Santos H, Capelo-Martinez JL, Poeta P, Igrejas G (2015) Effect of vancomycin on the proteome of the multiresistant Enterococcus faecium SU18 strain. J Proteome 113(0):378-387

Resch A, Leicht S, Saric M, Pasztor L, Jakob A, Gotz F, Nordheim A (2006) Comparative proteome analysis of Staphylococcus aureus biofilm and planktonic cells and correlation with transcriptome profiling. Proteomics 6(6):1867-1877

Richards AL, Merrill AE, Coon JJ (2015) Proteome sequencing goes deep. Curr Opin Chem Biol 24(0):11-17

Rigoutsos I, Stephanopoulos G (2006) Systems biology: volume II: networks, models, and applications. Oxford University Press, USA

Roberts SF, Fischhoff MA, Sakowski SA, Feldman EL (2012) Perspective: transforming science into medicine: how clinician-scientists can build bridges across research's "valley of death". Acad Med 87(3):266-270

Roe MR, Griffin TJ (2006) Gel-free mass spectrometry-based high throughput proteomics: tools for studying biological response of proteins and proteomes. Proteomics 6(17):4678-4687

Rosenberger G, Koh CC, Guo T, Röst HL, Kouvonen P, Collins BC, Heusel M, Liu Y, Caron E, Vichalkovski A, Faini M, Schubert OT, Faridi P, Ebhardt HA, Matondo M, Lam H, Bader SL, Campbell DS, Deutsch EW, Moritz RL, Tate S, Aebersold R (2014) A repository of assays to quantify 10,000 human proteins by SWATH-MS. Sci Data 1:140031

Rost HL, Rosenberger G, Navarro P, Gillet L, Miladinovic SM, Schubert OT, Wolski W, Collins BC, Malmstrom J, Malmstrom L, Aebersold R (2014) OpenSWATH enables automated, targeted analysis of data-independent acquisition MS data. Nat Biotechnol 32(3):219223

Samuel Reich E (2011) Cancer trial errors revealed. Nature 469(7329): $139-140$

Santoni V, Molloy M, Rabilloud T (2000) Membrane proteins and proteomics: un amour impossible? Electrophoresis 21(6):1054-1070

Savijoki K, Iivanainen A, Siljamaki P, Laine PK, Paulin L, Karonen T, Pyorala S, Kankainen M, Nyman TA, Salomaki T, Koskinen P, Holm L, Simojoki H, Taponen S, Sukura A, Kalkkinen N, Auvinen P, Varmanen P (2014) Genomics and proteomics provide new insight into the commensal and pathogenic lifestyles of bovineand human-associated Staphylococcus epidermidis strains. J Proteome Res. doi:10.1021/pr500322d

Scherl A, Francois P, Charbonnier Y, Deshusses JM, Koessler T, Huyghe A, Bento M, Stahl-Zeng J, Fischer A, Masselot A, Vaezzadeh A, Galle F, Renzoni A, Vaudaux P, Lew D, Zimmermann-Ivol CG, Binz PA, Sanchez JC, Hochstrasser DF, Schrenzel J (2006) Exploring glycopeptide-resistance in Staphylococcus aureus: a combined proteomics and transcriptomics approach for the identification of resistance-related markers. BMC Genomics 7:296

Schmidt S, Jacob S, Ahn S, Rupasinghe T, Krömer J, Khan A, Varela C (2013) Two strings to the systems biology bow: co-extracting the metabolome and proteome of yeast. Metabolomics 9(1):173-188

Scholler N, Urban N (2007) CA125 in ovarian cancer. Biomark Med 1(4):513-523

Sears CL, Garrett WS (2014) Microbes, microbiota, and colon cancer. Cell Host Microbe 15(3):317-328

Segata N, Boernigen D, Tickle TL, Morgan XC, Garrett WS, Huttenhower C (2013) Computational meta'omics for microbial community studies. Mol Syst Biol 9:666

Selvaraju S, El Rassi Z (2012) Liquid-phase-based separation systems for depletion, prefractionation and enrichment of proteins in biological fluids and matrices for in-depth proteomics analysis - an update covering the period 2008-2011. Electrophoresis 33(1):74-88

Shabbiri K, Botting CH, Adnan A, Fuszard M (2013) Charting the cellular and extracellular proteome analysis of Brevibacterium linens DSM 20158 with unsequenced genome by mass spectrometrydriven sequence similarity searches. J Proteome 83(0):99-118

Siggins A, Gunnigle E, Abram F (2012) Exploring mixed microbial community functioning: recent advances in metaproteomics. FEMS Microbiol Ecol 80(2):265-280

Silva AM, Vitorino R, Domingues MR, Spickett CM, Domingues P (2013) Post-translational modifications and mass spectrometry detection. Free Radic Biol Med 65:925-941

Simon I, Zhuo S, Corral L, Diamandis EP, Sarno MJ, Wolfert RL, Kim NW (2006) B7-h4 is a novel membrane-bound protein and a candidate serum and tissue biomarker for ovarian cancer. Cancer Res 66(3):1570-1575

Soler L, Niewold T, de Pauw E, Mazzucchelli G (2013) Small intestinal response to enterotoxigenic Escherichia coli infection in pigs as revealed by label free UPLC/MSE proteomics. Farm animal proteomics. Springer, pp. 55-58

Soloviev M, Barry R, Scrivener E, Terrett J (2003) Combinatorial peptidomics: a generic approach for protein expression profiling. J Nanobiotechnol 1(1):4

Soufi B, Krug K, Harst A, Macek B (2015) Characterization of the E. coli proteome and its modifications during growth and ethanol stress. Frontiers in. Microbiology 6:103

Soufi B, Soares NC, Ravikumar V, Macek B (2012) Proteomics reveals evidence of cross-talk between protein modifications in bacteria: focus on acetylation and phosphorylation. Curr Opin Microbiol 15(3):357-363

Southan C (2004) Has the yo-yo stopped? An assessment of human protein-coding gene number. Proteomics 4(6):1712-1726

Stastna M, Van Eyk JE (2012) Analysis of protein isoforms: can we do it better? Proteomics 12(0):2937-2948

Su YC, Wan KL, Mohamed R, Nathan S (2010) Immunization with the recombinant Burkholderia pseudomallei outer membrane protein Omp85 induces protective immunity in mice. Vaccine 28(31): 5005-5011

Sun CS, Markey MK (2011) Recent advances in computational analysis of mass spectrometry for proteomic profiling. J Mass Spectrom 46(5):443-456

Thelen JJ, Miernyk JA (2012) The proteomic future: where mass spectrometry should be taking us. Biochem J 444(2):169-181

Titz B, Elamin A, Martin F, Schneider T, Dijon S, Ivanov NV, Hoeng J, Peitsch MC (2014) Proteomics for systems toxicology. Comput Struct Biotechnol J 11(18):73-90

Tjalsma H, Schaeps RM, Swinkels DW (2008) Immunoproteomics: from biomarker discovery to diagnostic applications. Proteomics Clin Appl 2(2):167-180

Tsolakos N, Brookes C, Taylor S, Gorringe A, Tang CM, Feavers IM, Wheeler JX (2014) Identification of vaccine antigens using 
integrated proteomic analyses of surface immunogens from serogroup B Neisseria meningitidis. J Proteome 101(0):63-76

Twine SM, Petit MD, Shen H, Mykytczuk NC, Kelly JF, Conlan JW (2006) Immunoproteomic analysis of the murine antibody response to successful and failed immunization with live anti-Francisella vaccines. Biochem Biophys Res Commun 346(3):999-1008

Van Oudenhove L, Devreese B (2013) A review on recent developments in mass spectrometry instrumentation and quantitative tools advancing bacterial proteomics. Appl Microbiol Biotechnol 97(11):47494762

Van PT, Ganesan V, Bass V, Parthasarathy A, Schlesinger D, Minden JS (2014) In-gel equilibration for improved protein retention in 2DEbased proteomic workflows. Electrophoresis 35(20):3012-3017

VanBogelen RA, Neidhardt FC (1990) Global systems approach to bacterial physiology: protein responders to stress and starvation. FEMS Microbiol Ecol 7(2-3):121-127

Vlahou A (2013) Network views for personalized medicine. Proteomics Clin Appl 7(5-6):384-387

Vogel C, Marcotte EM (2012) Insights into the regulation of protein abundance from proteomic and transcriptomic analyses. Nat Rev Genet 13(4):227-232

Vranakis I, Goniotakis I, Psaroulaki A, Sandalakis V, Tselentis Y, Gevaert K, Tsiotis G (2014) Proteome studies of bacterial antibiotic resistance mechanisms. J Proteome 97:88-99

Wang H, Hanash S (2015) Mass spectrometry based proteomics for absolute quantification of proteins from tumor cells. Methods 81(0): 34-40

Wang K, Huang C, Nice E (2014a) Recent advances in proteomics: towards the human proteome. Biomed Chromatogr 28(6):848-857

Wang L, Cui J, Hu DD, Liu RD, Wang ZQ (2014b) Identification of early diagnostic antigens from major excretory-secretory proteins of Trichinella spiralis muscle larvae using immunoproteomics. Parasit Vectors 7:40

Washburn MP, Wolters D, Yates 3rd JR (2001) Large-scale analysis of the yeast proteome by multidimensional protein identification technology. Nat Biotechnol 19(3):242-247

Wasinger VC, Cordwell SJ, Cerpa-Poljak A, Yan JX, Gooley AA, Wilkins MR, Duncan MW, Harris R, Williams KL, Humphery-Smith I (1995) Progress with gene-product mapping of the mollicutes: Mycoplasma genitalium. Electrophoresis 16(7):1090-1094

Weinberger DM, Malley R, Lipsitch M (2011) Serotype replacement in disease following pneumococcal vaccination: a discussion of the evidence. Lancet 378(9807):1962-1973

Wendler S, Hürtgen D, Kalinowski J, Klein A, Niehaus K, Schulte F, Schwientek P, Wehlmann H, Wehmeier UF, Pühler A (2013) The cytosolic and extracellular proteomes of Actinoplanes sp. SE50/110 led to the identification of gene products involved in acarbose metabolism. J Biotechnol 167(2):178-189

Williams JN, Weynants V, Poolman JT, Heckels JE, Christodoulides M (2014) Immuno-proteomic analysis of human immune responses to experimental Neisseria meningitidis outer membrane vesicle vaccines identifies potential cross-reactive antigens. Vaccine 32(11): $1280-1286$

Wilson R (2013) Sensitivity and specificity: twin goals of proteomics assays. Can they be combined? Exp Rev Proteomics 10(2):135-149
Wolff S, Antelmann H, Albrecht D, Becher D, Bernhardt J, Bron S, Büttner K, van Dijl JM, Eymann C, Otto A, Tam LT, Hecker M (2007) Towards the entire proteome of the model bacterium Bacillus subtilis by gel-based and gel-free approaches. J Chromatogr B 849(1-2):129-140

Wu Q, Yuan H, Zhang L, Zhang Y (2012) Recent advances on multidimensional liquid chromatography-mass spectrometry for proteomics: from qualitative to quantitative analysis - a review. Anal Chim Acta 731(0):1-10

Wu Z, Zhang W, Lu C (2008a) Comparative proteome analysis of secreted proteins of Streptococcus suis serotype 9 isolates from diseased and healthy pigs. Microb Pathog 45(3):159-166

Wu Z, Zhang W, Lu C (2008b) Immunoproteomic assay of surface proteins of Streptococcus suis serotype 9. FEMS Immunol Med Microbiol 53(1):52-59

Wyres KL, Lambertsen LM, Croucher NJ, McGee L, von Gottberg A, Linares J, Jacobs MR, Kristinsson KG, Beall BW, Klugman KP, Parkhill J, Hakenbeck R, Bentley SD, Brueggemann AB (2013) Pneumococcal capsular switching: a historical perspective. J Infect Dis 207(3):439-449

Xie F, Liu T, Qian W-J, Petyuk VA, Smith RD (2011) Liquid chromatography-mass spectrometry-based quantitative proteomics. J Biol Chem 286(29):25443-25449

Yates JR, Speicher S, Griffin PR, Hunkapiller T (1993) Peptide mass maps: a highly informative approach to protein identification. Anal Biochem 214(2):397-408

Yergey AL (1990) Liquid chromatography/mass spectrometry: techniques and applications. Springer Science \& Business Media

Yin B, Whyatt RM, Perera FP, Randall MC, Cooper TB, Santella RM (1995) Determination of 8-hydroxydeoxyguanosine by an immunoaffinity chromatography-monoclonal antibody-based ELISA. Free Radic Biol Med 18(6):1023-1032

Yu CS, Chen YC, Lu CH, Hwang JK (2006) Prediction of protein subcellular localization. Proteins Struct Funct Bioinf 64(3):643-651

Zahedi RP, Ueffing M, Sickmann A (2014) Proteomics - moving from inventory to personalized medicine? Proteomics 14(17-18):1953-1953

Zhai Z, Li X, Xiao X, Yu J, Chen M, Yu Y, Wu G, Li Y, Ye L, Yao H (2013) Immunoproteomics selection of cross-protective vaccine candidates from Riemerella anatipestifer serotypes 1 and 2. Vet Microbiol 162(2):850-857

Zhang W, Li F, Nie L (2010) Integrating multiple 'omics' analysis for microbial biology: application and methodologies. Microbiology 156(2):287-301

Zhou M, Guo Y, Zhao J, Hu Q, Hu Y, Zhang A, Chen H, Jin M (2009) Identification and characterization of novel immunogenic outer membrane proteins of Haemophilus parasuis serovar 5. Vaccine 27(38):5271-5277

Zhou S, Bailey MJ, Dunn MJ, Preedy VR, Emery PW (2005) A quantitative investigation into the losses of proteins at different stages of a two-dimensional gel electrophoresis procedure. Proteomics 5(11): 2739-2747

Zhou Y, Shan Y, Zhang L, Zhang Y (2014) Recent advances in stable isotope labeling based techniques for proteome relative quantification. J Chromatogr A 1365(0):1-11 